Notes

\title{
A PUBLIC TRUST ARGUMENT FOR PUBLIC ACCESS TO PRIVATE CONSERVATION LAND
}

\author{
SARAH C. SMITH
}

\section{INTRODUCTION}

Urban renaissances notwithstanding, American cities have dramatically changed in the last fifty years. Downtowns and small towns are on the way out. Suburbs have replaced towns, and corporate campuses are preferred to skyscrapers in expanding cities. ${ }^{1}$ In general, people are building lower and wider. Necessarily, this kind of development requires land. As cities sprawl out, they incorporate more and more previously open land. Faced with changes they do not like, concerned residents have become activists, fighting to protect open space. And the first logical place to start is Washington, D.C.

The federal government owns twenty-nine percent of land in this country, predominantly in the western states and Alaska. ${ }^{2}$ Federal land management policies have developed as the country has grown, and many give greater preference to resource developers than preservationists would like. ${ }^{3}$ The ranching industry, for example, depends heavily on cheap federal grazing permits. ${ }^{4}$ Countering development

Copyright () 2002 by Sarah C. Smith.

1. See Robert Fishman, Beyond Suburbia: The Rise of the Technoburb, in THE CITY READER 490 (Richard T. LeGates \& Frederic Stout eds. 1996) (noting a shift in development from the traditional city/suburb model to an expanding metropolis model).

2. Dale A. Oesterle, Public Land: How Much Is Enough?, 23 Ecology L.Q. 521, 523 (1996).

3. See Joseph L. SaX, Mountains Without Handrails: Reflections on the NATIONAL PARKS 5, 7-9 (1980) (discussing the value judgments inherent in use decisions regarding the creation of the national parks); CHARLES F. WILKINSON, CROSSING THE NEXT MERIDIAN: LAND, WATER, AND THE Future OF THE WeSt 17 (1992) (arguing that outdated nineteenth-century policies still dominate land management in the West, to the detriment of the land itself).

4. Oesterle, supra note 2, at 527. 
interests, environmentalists dating from John Muir have lobbied for the pristine conservation of federal land. ${ }^{5}$ Trying to find the best course between solutions advocated by environmental interest groups, locals, state governments, industry, and the "national good," the agencies responsible for administering the federal holdings often succeed in pleasing no one. ${ }^{6}$

While some environmental groups continue to lobby for the preservation of federally held lands, other activists have opted to do it themselves. Land trusts are popular private alternatives to slowacting government agencies bogged down in bureaucratic regulations - and their use is growing. ${ }^{7}$ A land trust is a nonprofit organization that preserves land by acquiring it through purchase or donation and dedicating it to conservation. ${ }^{8}$ The amount of land protected by local and regional land use action has grown 226 percent since $1990 .^{9}$

Although land trusts are private, they benefit greatly from public support. Land trusts enjoy special tax treatment, both through their nonprofit status and through the federal conservation contribution tax deduction. ${ }^{10}$ This public subsidy signifies general approval of land trusts and their activities. The approval land trusts enjoy is not surprising. Because land trusts operate through voluntary transactions such as sales and donations, they are among the least controversial members of the environmental community. Unfortunately, the un-

5. Jan G. Laitos \& Thomas A. Carr, The Transformation on Public Lands, 26 EcOlogY L.Q. 140, 193-95 (1999).

6. Part of the difficulty facing these agencies may lie in the fact that there is no original mandate for the lands. See SAX, supra note 3, at 5 (commenting that "[w]hat exactly was meant to be accomplished by these unprecedented [national parks] is a mystery that will never be fully solved").

7. See, e.g., Julie Ann Gustanski, Protecting the Land: Conservation Easements, Voluntary Actions, and Private Lands, in Protecting the LAND: Conservation EASEMENTS PAST, PRESENT, AND FutURE 17-18 (Julie Ann Gustanski \& Roderick H. Squires eds., 2000) [hereinafter PROTECTING THE LAND] (commenting that the dramatic increase in land trusts is fueled in part by conservationists' disappointment in the government's ability to protect open space).

8. SAlly K. Fairfax \& Darla Guenzler, Conservation Trusts 21 (2001). Even though some organizations that differ from the description above nonetheless call themselves "land trusts," this Note uses the Fairfax and Guenzler definition for clarity's sake.

9. See Summary Data from the National Land Trust Census, Land Trust Alliance, at http://www.lta.org/newsroom/census_summary_data.htm (Sept. 12, 2001) (on file with the Duke Law Journal) (attributing the amount of land protected to three sources: conservation easements, land owned by trusts, and land transferred to government or other organizations). The Census actually undercounted the amount of land privately protected because it only counted land in local and regional land trusts, to the exclusion of land held by national and international land trusts such as the Nature Conservancy. Id.

10. See infra Part I. 
foreseen impacts of land trust activity may actually disadvantage the general public.

Most importantly, land trusts could lead to a diminution of the open space that is actually available to the public. Because the land trusts become private owners of the land, they acquire the right to exclude as well as the right to conserve. The initial question that arises is whether the favorable tax treatment that the land trusts receive justifies imposing a public access requirement. Assuming that such a requirement is necessary, the next question is how such public access is to be provided. The goal of this Note is to examine the various legal mechanisms available.

This Note first describes what a land trust is and how it operates. Next, this Note briefly discusses why land trusts pose a risk to open space availability as well as why they should be required to provide public access. Then, this Note argues that the public trust doctrine already provides for limited public access to some of the land held by land trusts. Because the public trust doctrine does not authorize access that would harm the land, access is necessarily limited. Finally, the Note sketches the public trust response to the two major arguments against public access, the takings challenge and the environmental consequences of public access.

\section{The NeEd FOR Public ACCESS}

Before exploring the details of the access debate, it is necessary to give context to the controversy. What are land trusts, and how could they be considered harmful?

\section{A. Land Trusts}

The term "land trust" is a loose one. It has no legal definition, and has been claimed by a variety of different organizations. ${ }^{11}$ Put very generally, a land trust is an organization that works to protect

11. FAirfaX \& GUENZler, supra note 8, at 21; see also LAND Trust Alliance, STARTING A LAND TRUST: A GUIDE TO FORMING A LAND CONSERVATION ORGANIZATION 1 (1990) (discussing the many ways in which land trusts are involved in conservation); Nancy A. McLaughlin, The Role of Land Trusts in Biodiversity Conservation on Private Lands, 38 IDAHO L. REV. 453, 453 (2002) (noting a recent explosion in "the number of private nonprofit organizations, typically referred to as 'land trusts"'). 
land from development. ${ }^{12}$ Usually land trusts are nonprofit organizations, ${ }^{13}$ but, beyond that, the similarities end. Despite the term "trust," land trusts are not usually organized under trust principles. ${ }^{14}$ In its guide to forming a land trust, the Land Trust Alliance notes that the unifying feature tying together all land trusts is "their first-hand involvement in land transactions or management."

Land trusts can be involved in all steps of the conservation process. Most are involved in some, but not all of these steps. They can acquire land through all of the mechanisms described below. ${ }^{16}$ Once it has acquired the land, the land trust can either manage the land itself or transfer it to another organization-either another land trust or a government entity. ${ }^{17}$ Some land trusts provide assistance in conservation transactions without actually participating by negotiating, researching, or lending their expertise. ${ }^{18}$

The most straightforward way for a land trust to protect a piece of land is to buy the land. Once it becomes an owner of the land, the land trust may use its fee ownership to control all activities on the land. Purchase is one of the most common land trust conservation activities, but donation may actually eclipse purchase in terms of frequency of occurrence. ${ }^{19}$ While a land trust must find the funds to make a purchase, the costs to accept a donation are minimal. When the donation is made to a "qualified" organization as defined by sec-

12. See FAIRFAX \& GUENZLER, supra note 8 , at 21 (defining a land trust as a nonprofit organization that preserves land by acquiring it through purchase or donation and dedicating it to conservation).

13. $I d$.

14. Id. at 21-22.

15. LAND TRUST AlLIANCE, supra note 11, at 1.

16. See FAIRFAX \& GUENZLER, supra note 8, at 21 (describing the five basic techniques land trusts use: purchase of land, acceptance of donations of land, purchase of conservation easements, acceptance of donations of conservation easements, and the acquisition of land or conservation easements to later reconvey to another organization); LAND TRUST ALLIANCE, supra note 11, at 1 (explaining the various ways a land trust can be involved in conservation, including purchase or acceptance of donations of land or conservation easements, managing land, and acting as a middle man in conservation negotiations); infra notes 19-31.

17. FAIRFAX \& GUENZLER, supra note 8, at 21.

18. LAND TRUSt Alliance, supra note 11, at 1. For example, the Trust for Public Land sees itself as a middleman in conservation transactions. See the Trust for Public Land, at http://www.tpl.org/tier2_sa.cfm?folder_id=170 (last viewed January 13, 2002) (on file with the Duke Law Journal) (describing how the Trust for Public Land uses its expertise to help communities raise funds for open space and manage the legal and real estate complexities of the transactions).

19. See Gustanski, supra note 7, at 10 (demonstrating that land purchase and land donation make up almost half of land trust activity). 
tion 170(h) of the Internal Revenue Code, the donor may deduct the value of the contribution from her tax return-a significant financial incentive. ${ }^{20}$

In recent years a new tool, the conservation easement, has emerged as a less expensive alternative to outright sale or donation that still provides the desired legal protection for conservation. A conservation easement is a "legally binding agreement that permanently restricts the development and future use of the land to ensure protection of its conservation values." ${ }^{21}$ It is best conceptualized as one stick out of the bundle of rights that comprise fee ownership. ${ }^{22}$ The original owner retains most of the ownership but cedes to the land trust the right to engage in various ecosystem-disturbing activities-such as construction or earthmoving-which, of course, the trust covenants not to exercise..$^{23}$ Essentially, the conservation easement is a negative easement, but it does not meet the traditional requirement that negative easements be appurtenant. ${ }^{24}$ Conservation easements do not have to meet this requirement because they are not part of the

20. I.R.C. § 170(h) (2002). The definition of a "qualified" organization includes almost any government entity, as well as charitable organizations that receive substantial public support, including some organizations that meet the requirements of section 501(c)(3). Id. § 170(b)(1)(A). To keep this tax status, land trusts may not lobby, engage in political campaigns, take action that would benefit a single private shareholder or individual, or receive the bulk of its support from any source other than the public. $I d$. § 501(c)(3). A recent case made that inducement less attractive in certain circumstances. The Fourth Circuit held that donations of mineral-rich land by a mining company to a land trust created an antitrust claim for the mining company's primary rival against the donor and the land trust. Va. Vermiculite, Ltd. v. W.R. Grace \& Co., 156 F.3d 535, 537-41 (4th Cir. 1998). This case, however, is not likely to have a significant chilling effect on the rate of donations because its facts are relatively unique. See id. at 537-38 (stating that (1) the mineral in question, vermiculite, was very rare; (2) the land donated held over forty percent of the known vermiculite in the United States; and (3) the case involved the only two domestic vermiculite producers in the country).

21. Gustanski, supra note 7, at 9.

22. Federico Cheever, Environmental Law: Public Good and Private Magic in the Law of Land Trusts and Conservation Easements: A Happy Present and a Troubled Future, 73 DENV. U. L. REV. 1077, 1079-80 (1996).

23. In practical terms, these restrictions would prevent subdivision and development, commercial and industrial use, altering the land surface, mining, dumping waste, adding lines or signs, or taking any action that would disturb the natural habitat, including the soil, water, and vegetation. JANET DIEHL \& THOMAS S. BARRETT, THE CONSERVATION EASEMENT Handbook: Managing Land Conservation AND Historic PRESERVATION EASEMENT PROGRAMS 177 (1988).

24. Cheever, supra note 22 , at 1080-81. 
common law-they are statutory creations of the state..$^{25}$

State statutes place a number of restrictions on conservation easements. Most states allow only two types of entities to hold conservation easements: government agencies with the authority to hold interest in real property, and charitable organizations dedicated to preserving "natural, scenic, or open-space values of real property." ${ }^{26}$ States vary in the strictness with which they approach these requirements. ${ }^{27}$ Some states even impose further requirements, such as maintenance and upkeep standards, on holders of conservation easements. ${ }^{28}$ Very few states impose a public access requirement. ${ }^{29}$

Conservation easements have become increasingly popular, and are quickly outstripping fee simple acquisition (through purchase or donation) as the preferred method of conservation. ${ }^{30}$ They are augmented by a multitude of other tools available for use as the occasion warrants-including, for example, options, land exchanges, deed restrictions, leases, restricted sales, and other agreements. ${ }^{31}$ Depending on the land trust's mission and focus, it will use some or all of these tools.

25. Id. at 1080 . As of 2000 , twenty-one states had adopted a conservation easement statute that was directly influenced by the Uniform Conservation Easement Act (UCEA). Todd D. Mayo, A Holistic Examination of the Law of Conservation Easements, in Protecting THE LAND, supra note 7, at 28-30. An additional twenty-five states have adopted conservation easement statutes that are not based on the UCEA. Id. Land trusts in states without conservation easement statutes may attempt a common law conservation easement, but those are much more vulnerable to legal attack. See Jeffrey Tapick, Threats to the Continued Existence of Conservation Easements, 27 COLUM. J. ENVTL. L. 257, 265-72 (2002) (detailing the arguments that could be made against a common-law conservation easement).

26. Cheever, supra note 22, at 1084 (quoting UNIF. CONSERVATION EASEMENT ACT $\S$ 1(2)(ii), 12 U.L.A. 170, 170 (1996)).

27. See Mayo, supra note 25 , at 35-40 (describing the variation among states in holder requirements).

28. See id. at 31-35 (listing the states that impose affirmative duties on holders of conservation easements).

29. See, e.g., Karin Marchetti \& Jerry Cosgrove, Conservation Easements in the First and Second Federal Circuits, in PRotecting THE LAND, supra note 7, at 79, 82 (describing the statutory language and terminology that relate to conservation easements in the states that are part of the specified Circuit); Melanie Pallone, Conservation Easements in the Third Circuit, in PROTECTING THE LAND, supra note 7, at 150 (same); John F. Rohe, Conservation Easements in the Sixth Federal Circuit, in PROTECTING THE LAND, supra note 7, at 270 (same); supra note 28 and accompanying text.

30. See Gustanski, supra note 7, at 14 (tracing the rise in acreage protection by conservation easements as opposed to fee title ownership).

31. Id. at 10 (cataloguing in a pie chart the various activities undertaken by land trusts). 
In addition to varying by their activities, land trusts also differ in their scope and focus. Some are dedicated only to one piece of land. ${ }^{32}$ Others, such as the Nature Conservancy, pursue a much larger land protection agenda. ${ }^{33}$ Still others focus on protecting only a certain type of land, such as farmland, ${ }^{34}$ battlefields, ${ }^{35}$ backcountry, ${ }^{36}$ or urban open space. ${ }^{37}$ This Note focuses on the actual management of lands by land trusts, irrespective of either the method of acquisition or the ultimate goal.

\section{B. Policy Arguments for Access}

Land trusts are involved in work that would almost universally be considered beneficial: preserving land from development while at the same time fairly compensating private owners of the land. Why, then, would anyone want to interfere with their operation by demanding public access onto the conserved land? Land trusts receive a significant public subsidy in the form of tax benefits. Implicit in any public subsidy is the belief that the activity of the organization is beneficial to society. Land trusts, however, do not provide any immediate benefits beyond conservation. A public access requirement would balance the exchange between public subsidy and public benefit.

32. See, e.g., Eno River Association, at http://www.enoriver.org (last visited Jan. 21, 2003) (on file with the Duke Law Journal) (preserving land in the Eno River basin near Durham, North Carolina); Truckee Donner Land Trust, at http://www.tdlandtrust.org (last visited Jan. 13, 2003) (on file with the Duke Law Journal) (preserving land in the "Truckee and North Tahoe" area of California).

33. LAND TRUST ALLIANCE, supra note 11, at 1 (noting the various level of involvement in conservation by trusts). To date, The Nature Conservancy has protected over ninety-eight million acres of land worldwide, including fourteen million acres in the United States. Nature Conservancy, About Us, at http://nature.org/aboutus/ (last visited November 26, 2002) (on file with the Duke Law Journal).

34. See, e.g., Merced County Farmlands and Open Space Land Trust, Our History and Mission, at http://www.mcfost.org/html/about\%20mcfost.html (last visited on Nov. 22, 2002) (on file with the Duke Law Journal) (protecting farmland in Merced County, California).

35. See, e.g., Civil War Preservation Trust, Our Mission, at http://www.civilwar.orgs/mission. html (last visited Nov. 22, 2002) (on file with the Duke Law Journal) (working to preserve Civil War battlefields in nineteen states).

36. See, e.g., Wilderness Land Trust, Recovered Land, at http://www.wildernesslandtrust. org/recoveredland.html (Nov. 13, 2002) (on file with the Duke Law Journal) (dedicated to preserving wilderness areas in multiple western states).

37. See, e.g., Saving the Endangered Coast, Peninsula Open Space Trust, at http://www.open spacetrust.org/ (last visited Nov. 22, 2002) (on file with the Duke Law Journal) (preserving land on the San Francisco Peninsula). 
Land trusts benefit from the tax code in two ways. First, those that qualify as section 501(c)(3) organizations are exempt from federal income $\operatorname{tax}^{38}$ Second, land trusts receive additional favorable treatment from the Internal Revenue Code in that they may solicit donations of land and conservation easements pursuant to the qualified conservation contribution deduction. ${ }^{39}$ These two benefits are subsidies that the public grants to land trusts because it supports their activity and wants to encourage it.

Although Congress has approved the trade-tax subsidy for land conservation - it is not clear that the realities of the trade are even. When land trusts manage conservation contribution lands, the only real requirement the Internal Revenue Code imposes is that the land be protected from development. ${ }^{40}$ Moreover, when Congress approved the deduction, there was no evidence that the members voting for it had carefully balanced the merits of the trade. ${ }^{41}$ Conservation easements sometimes impose affirmative duties on the holder of the easement to maintain the land, but that is the exception, not the rule. $^{42}$ Even when affirmative duties are imposed, they almost never include a right of public access to the conserved land. ${ }^{43}$

If a land trust is only required to preserve land from development, it is providing only an existential benefit, ${ }^{44}$ which is generally understood as the psychological value the land provides by simply existing in its preserved state. Environmental activist Edward Abbey succinctly described this position, "[w]e need wilderness whether or not we ever set foot in it .... I may never in my life get to Alaska, for

\footnotetext{
38. I.R.C. § 501(a) (2002).

39. Id. $\S 170(\mathrm{~h})$ (stating the general requirements for contributing individual property).

40. The conservation contribution deduction requires that the land serve a "conservation purpose," and describes a wide range of uses that qualify; all of these uses, however, would preclude any sort of development on the land. Id. $\$ 170(\mathrm{~h})(4)(\mathrm{A})$. The terms of the deduction have been favorably construed in Internal Revenue Service (IRS) private letter rulings, assuring land trusts and donors that the requirements will not be harshly challenged. Stephen J. Small, $A n$ Obscure Tax Code Provision Takes Private Land Protection into the Twenty-First Century, in PROTECTING THE LAND, supra note 7, at 57-60.

41. See Small, supra note 40, at 56-57 (noting that there was little debate when the first form of the deduction was adopted and that very few interest groups were involved in drafting the legislation that made the deduction permanent).

42. See Mayo, supra note 25, at 31-35 (listing the states that impose affirmative duties on holders of conservation easements).

43. See supra note 29 and accompanying text.

44. See Laitos \& Carr, supra note 5, at 228 (stating that "[e]xistence value defines the satisfaction an individual derives from knowing a resource continues to exist, even if that person never personally uses the resource and will not likely do so in the future").
} 
example, but I am grateful that it's there." 45 This espousal of the existential benefit is the classic preservationist position.

In contrast, if the land trust were to provide public access, it would also provide an additional public benefit: the recreational benefit. Unlike Abbey, a recreationist would value Alaska for the "play" opportunities ${ }^{46}$ it offers, and would view the preservationist philosophy with suspicion. ${ }^{47}$ Moreover, because the law currently favors the preservationist point of view by requiring taxpayers to subsidize it, imposing a public access requirement would probably increase the taxpayers' perceived return on their "investment."

Finally, in addition to their potential to cordon off their own land, land trusts could have a negative impact on public access to public land. If the government were, in recognition of the land trusts' activities, to slow its own acquisition and preservation of land, a perpetually increasing percentage of American open land would be in private hands. Already, there are signs that government is being left behind in the preservation business: private conservation easement donors have recently been preferentially donating to private land

45. Id. at 194 (quoting EdWARd AbBey, Desert Solitaire: A SEASON IN THE WILDERNESS 129 (1968)).

46. Recreationists are not in agreement about what qualifies as "good" recreation. For example, nonmotorized recreationists continually criticize jet-skiers and snowmobilers for their heavier impact on the environment. See Arthur Allen, Where the Snowmobiles Roam; What's Worth More, Unspoiled Wilderness or the Sacred Bond Between a Man and a Really Loud Machine?, WASH. POST MAG., Aug. 18, 2002, at W15 (describing the push toward regulating the use of snowmobiles); Susan Sward \& Jim Doyle, Setback for Tahoe Jet-Skiers; Judge Rules for Protection of Lake, S.F. CHRON., Oct. 7, 1988 at A15 (describing the ban on jet-skis and motorboats at Lake Tahoe). Dale A. Oesterle satirized the hierarchy of "outdoorsy" virtue as follows:

$[\mathrm{H}] \mathrm{ikers}$ (other than those in wheelchairs and those who are out of shape) and wildlife watchers (other than those in helicopters) are more deserving than campers (other than backpackers, see hikers), who (with the exception of those driving recreational vehicles) are more deserving than mountain bikers, who are more deserving than downhill (but not cross-country) skiers, who are more deserving than hunters (but not fisherpersons, see hikers), who are more deserving than off-road motorcyclists.

Oesterle, supra note 2, at 549. This Note does not take a position on what kind of recreational activities are appropriate because that decision is necessarily one that must be made in response to the condition of the particular piece of land, among other factors.

47. See SAX, supra note 3, at 2:

Attitudes toward nature and recreational preferences seem purely matters of private taste. The auto tourist sees himself as every bit as virtuous as the backpacker. The preservationist often appears as nothing more than the voice of effete affluence, trying to save a disproportionate share of the public domain for his own minoritarian pleasures. 
trusts rather than to the government. ${ }^{48}$ If this pattern were to continue, the wild and majestic parts of America-not to mention the greenbelts and farmland-could be preserved, but the public would only see them in photographs, if at all.

As private landholders, the land trusts have the right to exclude all comers from their property unless the conservation easement on the land specifically provides otherwise. Land trusts could also provide special access privileges to their members. ${ }^{49}$ If a land trust enforced its fee simple rights, only those who could pay the membership fee could gain entrance. This would lead to a worrying situation in which the wealthy would have access to these eco-reserves, but the general public would not. True, the land is preserved for future generations, but the present generation gets nothing more than the psychological benefit of knowing that the land is protected.

\section{Public Trust Doctrine}

While there are many different ways for public access proponents to change the current system to make future conservation holdings open to the public, ${ }^{50}$ the arguments for immediate access are more limited. Of these arguments, the public trust doctrine is one of the most promising.

The theory of the public trust is an ancient common law doctrine. ${ }^{51}$ Described simply, the public trust doctrine provides that, because natural resources belong to the public as a whole, private owners may not deprive the public of access. Traditionally, the public trust protected beaches and navigable waterways so that commerce could proceed unimpeded. ${ }^{52}$ In the last fifty years, however, both the scope and the purpose of the public trust doctrine have changed.

\footnotetext{
48. See Gustanski, supra note 7, at 17 (describing the transition of conservation easements from government to private hands).

49. See Nature Conservancy, Travel, at http://nature.org/aboutus/travel/ (last visited November 26, 2002) (on file with the Duke Law Journal) (advertising special travel arrangements on Nature Conservancy land).

50. See infra notes $115-17$ and accompanying text.

51. See Susan Morath Horner, Embryo, Not Fossil: Breathing Life into the Public Trust Doctrine in Wildlife, 35 LAND \& WATER L. REV. 23, 31 (2000) (describing the public trust doctrine as having roots in early Roman civil law).

52. Dennis J. Coyle, Property Rights and the Constitution: Shaping Society Through Land Use Regulation 224 (1993); Richard J. Lazarus, Changing Conceptions of Property and Sovereignty in Natural Resources: Questioning the Public Trust Doctrine, 71 IowA L. REV. 631, 636 (1986).
} 


\section{A. Development of the Theory}

The public trust is a common law doctrine that has developed slowly through judicial decisions, but the idea itself predates the common law. The concept of the public trust is traditionally considered to date back to Roman law, ${ }^{53}$ although some believe it may be even older. ${ }^{54}$ After centuries of lapse, the doctrine that certain lands always belong to the sovereign was revived in England during the early seventeenth century to augment the declining fortunes of the Crown. ${ }^{55}$ When the colonists came to the Americas, they brought the doctrine, although they changed its beneficiary from the monarchy to the public as a whole. ${ }^{56}$ According to Martin v. Waddell, ${ }^{57}$ the thirteen original colonies held title to their tidal waterways when they entered the Union, never surrendering their territory to the federal government. ${ }^{58}$ The subsequent states were deemed to have taken title to their respective tidal lands upon entry into the Union under the Equal Footing Doctrine. ${ }^{59}$ Thus, the idea that the government-on behalf of the Crown or the People-has an interest in land that can supercede an individual owner's right is an ancient and established part of the common law.

Throughout the nineteenth century, the public trust doctrine was static. The shorelines and land underlying navigable rivers were held to be in the "public trust." ${ }^{, 60}$ This status limited, and continues to limit, the actions that a private property owner could take on these lands to

53. Lazarus, supra note 52, at 633.

54. See Horner, supra note 51, at 31 (noting that some commentators believe that the public trust doctrine may have roots in ancient Greece).

55. See id. at 35-37 (describing the role of the public trust in the power struggles of sixteenth- and seventeenth-century England); Carol M. Rose, Takings, Public Trust, Unhappy Truths, and Helpless Giants: A Review of Professor Joseph Sax's Defense of the Environment Through Academic Scholarship: Joseph Sax and the Idea of the Public Trust, 25 EcOlOGY L.Q. 351, 351 (1998) (alluding to the role of the public trust in debates on the royal prerogative).

56. See Lazarus, supra note 52, at 636 (stating that the nineteenth-century jurists specifically included jus publicum, the rights of the general public, in their division of water rights).

57. 41 U.S. (16 Pet.) 367 (1842).

58. Id. at 410; see also Horner, supra note 51, at 38 (describing the process by which the public trust doctrine was solidified in the United States); Lazarus, supra note 52, at 637 (characterizing Martin v. Waddell as holding that states own the beds of navigable water "in their sovereign capacity").

59. See Horner, supra note 51, at 38 (noting that the states were admitted to the Union after the first thirteen took title to their tidelands under the Equal Footing Doctrine).

60. Charles F. Wilkinson, The Headwaters of the Public Trust: Some Thoughts on the Source and Scope, 19 ENVTL. L. 425, 454-55 (1989). 
actions that did not interfere with the public trust. ${ }^{61}$ Private property rights with respect to land in the public trust were subordinate to the public trust. The nineteenth century public trust was one of negative rights. While it prevented harmful action, it imposed no affirmative duties on the landowner or the state to care for the land.

Just before the turn of the century, Illinois Central Railroad Co. $v$. Illinois ${ }^{62}$ changed the nature of the public trust nationally by establishing the basic affirmative responsibilities of the states with respect to the public trust. ${ }^{63}$ The Supreme Court held that a state cannot sell land that is held in public trust, nor can it transfer away its fiduciary responsibilities toward the land. ${ }^{64}$ After Illinois Central Railroad, the concept lay dormant, confined to waterways, until Professor Joseph Sax published his groundbreaking article on the public trust. ${ }^{65}$ Professor Sax argued that the principle of public trust extends far beyond the traditional realms of waterways and parklands. He claimed that "[p]ublic trust problems are found whenever government regulation comes into question, and they occur in a wide range of situations in which diffuse public interests need protection against tightly organized groups with clear and immediate goals." ernment has an additional affirmative duty to protect the public resources that are part of the public trust. Since the article was written, judges across the country have been changing the nature of the public trust through decisions that broaden its geographic protections, and widen the range of activities it encompasses. ${ }^{67}$

61. See COYLE, supra note 52, at 224-25 (arguing that the public trust doctrine has been applied beyond its original commercial intentions to include preservation and environmental motives).

62. 146 U.S. 387 (1892).

63. See Lazarus, supra note 52, at 640 (calling the Illinois Central decision a "lodestar" in part because judges still use its reasoning to justify their decisions).

64. Ill. Cent. R.R. Co., 146 U.S. at 437, 452-53.

65. See Rose, supra note 55, at 352 (arguing that Professor Sax "ushered in the ... most recent major revival of the public trust concept" by "unhook[ing] it from its traditional moorings on or around water bodies and appl[ying] it to dry land" (citing Joseph L. Sax, The Public Trust Doctrine in Natural Resources Law: Effective Judicial Intervention, 68 MICH. L. REV. 471 (1970))).

66. Sax, supra note 65 , at 556 .

67. In the 1980s, it appeared that the public trust expansion was ending, and that contraction was in sight. See Lazarus, supra note 52, at 713-14 (arguing that recent Supreme Court cases, including Kaiser Aetna v. United States, 444 U.S. 164 (1979), presaged the beginning of the end for the "environmental" public trust doctrine). The Supreme Court, however, seems to have avoided a repudiation of an environmental interpretation of the public trust doctrine. See Phillips Petroleum Co. v. Mississippi, 484 U.S. 469, 475 (1988) (holding that states have the right to determine the extent of their public trusts). 


\section{B. Geographic Breadth of the Trust}

Whether the public trust argument allows for public access to private conservation land depends on the state. ${ }^{68}$ At a minimum, land trusts that own land on which there is a navigable waterway must allow public navigation on the waterway. ${ }^{69}$ If, however, the state has adopted a broader interpretation of the public trust, as has California, ${ }^{70}$ the land trust would be subject to public trust restrictions through all the tiny tributaries on the land. Because of the fractal nature of watershed drainage systems, that makes for pervasive control. Tributaries collect water from every part of the land surface, joining together to make larger streams, and then rivers, and eventually draining into the ocean. While navigable waterways are necessarily substantial enough for a watercraft (and therefore identifiable), tributaries are everywhere and can be quite small. California's ruling significantly extends the public trust inland by including everything from the Colorado River to the tiniest mountain stream to a desert gully that carries water from time to time.

After the Sax article was published, the California Supreme Court extended the public trust inland from the shore in a series of cases. From its original definition in terms of commerce, navigation, and fishing, ${ }^{71}$ the court broadened the doctrine of the public trust in California. First, two cases established the primacy of the public trust in tidelands, even in cases where those lands were legally sold to private owners under state authorization. ${ }^{72}$ After these cases were de-

68. See Phillips Petroleum Co., 484 U.S. at 475 (affirming that states have "the authority to define the limits of the lands held in public trust and to recognize private rights in such lands as they see fit").

69. See supra notes 52-59 and accompanying text.

70. See infra notes 76-78 and accompanying text.

71. See Marks v. Whitney, 491 P.2d 374, 380 (Cal. 1971) (defining these terms to include the rights to fish, hunt, bathe, swim, and use for boating or general recreation purposes the navigable waters of the state).

72. See City of Los Angeles v. Venice Peninsula Props., 644 P.2d 792, 794 (Cal. 1982) (describing how the owner traced title to a Mexican grant that was affirmed by federal patent processes); City of Berkeley v. Superior Court, 606 P.2d 362, 363 (Cal. 1980) (stating that the private company had purchased the land from the state in a sale that was authorized for the benefit of the public trust); COYLE, supra note 52, at 131-32 (discussing the importance of Berkeley and Venice Peninsula in setting new public trust precedent). 
cided it was clear that private property owners of tidelands could not rely on any supposed exemptions from the public trust. ${ }^{73}$

The next expansion of the public trust in California occurred in a second pair of cases in which the California Supreme Court held that the shores of both Clear Lake and Lake Tahoe were part of the public trust. ${ }^{74}$ Consequently, by extension, all inland lakes were included in the public trust.

The most recent extension of the public trust came at the expense of government. In National Audubon Society v. Superior Court $^{76}$ the court was faced with the problem of Los Angeles County taking vast amounts of water from Mono Lake, thereby dangerously depleting it. ${ }^{77}$ The court held that all tributaries are part of the public trust on the ground that, because the public trust already protected navigable waterways, it made sense to protect the waterways from upstream degradation as well. ${ }^{78}$

The extension of the public trust in California stopped there, but the possible future is not hard to see. If tributaries are part of the public trust because of their impact on navigable waterways, there is no scientific barrier from declaring the entire watershed part of the public trust. The tributaries themselves are formed by water flowing over the land into small streams. ${ }^{79}$ Eventually the California public trust doctrine could break free from its water-based origins to apply to all natural resources, as Professor Sax foresaw.

Other states have not followed such a hydrologic approach to the public trust, but they have extended its reach nonetheless. Where the public trust traditionally only protected the wet sand of a beach, it has

73. See COYLE, supra note 52, at 132 (stating that the California court held that all lands bordering navigable waters in the state could be "subject to the trust obligations of preservation").

74. State v. Superior Court, 625 P.2d 239, 252 (Cal. 1981) (holding that an owner of land along the shorelines of navigable nontidal waters - in this case, Clear Lake-had title to land between the high and low water marks, but that the title was subject to the public trust); State v. Superior Court, 625 P.2d 256, 260 (Cal. 1981) (holding that boundaries between public and private lands should be determined with reference to the lake's-in this case, Lake Tahoe's-current condition).

75. COYLE, supra note 52, at 132.

76. Nat'l Audubon Soc'y v. Superior Court, 658 P.2d 709 (Cal. 1983).

77. Id. at 711.

78. Id. at 720-21.

79. See M.J. Selby, Hillslope Materials And Processes 214-18 (1993) (explaining how rainfall runs across and through the ground to reach streams and rivers). 
also been extended to protect dry sand on a beach..$^{80}$ The trust has also been extended to include wildlife ${ }^{81}$ and parklands. ${ }^{82}$ Some states have even adopted legislation or constitutional amendments declaring that all publicly held natural resources are subject to the public trust. ${ }^{83}$ The few codifications of the public trust notwithstanding, it remains primarily a common law doctrine applicable to all land, not just land owned by the state, and will likely continue to develop on a case-bycase basis in each state.

\section{Activities Protected by the Trust}

The activities protected by the public trust also vary. At a minimum, the public trust protects navigation and fishing. ${ }^{84}$ Some states have chosen to limit their public trusts to that level. For example, Massachusetts took a restrictive interpretation of the right to walk along beaches. ${ }^{85}$ Faced with the question of whether the public trust access right to walk along beaches included the right to recreate at the beach, the justices concluded that the right of access was a right of passage only and did not extend to recreational activities while on the public trust land. ${ }^{86}$ Maryland has similarly rejected a chance to extend the public access rights of the public trust. ${ }^{87}$

States are split between limited access, such as that allowed in Maryland and Massachusetts, and a more broad right of access. Many

80. Van Ness v. Borough of Deal, 393 A.2d 571, 573 (N.J. 1978) (holding that dry beach is part of the New Jersey public trust, even when the beach has been substantially improved by a private owner).

81. Wade v. Kramer, 459 N.E.2d 1025, 1027-28 (Ill. App. Ct. 1984) (recognizing that wildlife is part of the Illinois public trust, but reasoning that the legislature has the authority to determine when public need for transportation overrides the public interest in wildlife, and refusing to stop the construction of a bridge that would cause some environmental damage).

82. Parsons v. Walker, 328 N.E.2d 920, 926 (Ill. App. Ct. 1975) (implying that the Illinois public trust includes public parks).

83. See Horner, supra note 51, at 58-72 (describing the varying success that Louisiana, Pennsylvania, Hawaii, Alaska, and Florida have had with codifications of the public trust).

84. See Ill. Cent. R.R. Co. v. Illinois, 146 U.S. 387, 456-59 (1892) (discussing the history of the public trust doctrine, including the traditional protection of navigation and fishing, to support the conclusion that the beds underlying navigable waters are part of the public trust in every state).

85. See Opinion of the Justices to the House of Representatives, 313 N.E.2d 561, 566 (Mass. 1974) (holding that the Massachusetts public trust doctrine does not include the right to walk on the beach for bathing).

86. Id.

87. Dep’t of Natural Res. v. Mayor \& Council of Ocean City, 332 A.2d 630, 638 (Md. 1975) (rejecting an extension of Maryland's public trust doctrine to include recreational interests). 
states, including those that have recently examined the issue, have significantly broadened the trust to include a wide range of activities. ${ }^{88}$ Most importantly for purposes of this Note, several states have found that the public trust includes a right to recreation. ${ }^{89}$ For example, the public trust in Wisconsin includes the rights to sailing, swimming, hunting, and enjoying scenic beauty. ${ }^{90}$ In a more recent case, Washington courts affirmed expansive access rights in the Washington public trust, but acknowledged that the court must balance the benefits of allowing access and protecting the environment. ${ }^{91}$ In that case, the court held that the public trust rights of access do not include the right to use jet-skis that are harmful to water and wildlife. ${ }^{92}$

Instead of cataloging the activities that are protected by the public trust, New Jersey has conceptualized the trust differently. The Supreme Court of New Jersey declared that the public trust is a flexible concept that changes with the changing needs of the population. ${ }^{93}$ In Borough of Neptune City v. Avon-By-The-Sea, the court concluded that the public trust doctrine forbids municipalities from discriminating between residents and nonresidents when charging user fees for the beach-access must be provided equally to all. ${ }^{94}$ Using this kind of reasoning, a court would be free to go beyond the classic fishing and navigation activities to find a broader recreational interest in the public trust.

88. See, e.g., Larman v. State, 552 N.W.2d 158, 161 (Iowa 1996) (stating that the public trust doctrine encompasses recreational uses); State v. Longshore, 5 P.3d 1256, 1262-63 (Wash. 2000) (declaring that the public trust in Washington includes "incidental rights" such as boating and swimming as well as the right to navigation).

89. Gion v. City of Santa Cruz, 465 P.2d 50, 58-60 (Cal. 1970) (holding that the California public trust recreational interest is superior to the private property interest); Gerwitz v. City of Long Beach, 330 N.Y.S.2d 495, 511-12 (N.Y. Sup. Ct. 1972) (holding that the New York public trust recreational interest is superior to a municipal interest); Weden v. San Juan County, 958 P.2d 273, 283-85 (Wash. 1998) (acknowledging that the Washington public trust includes an interest in fishing, boating, waterskiing, and other recreational purposes, but declining to extend a protected right to operate personal watercrafts that were hazardous to the water and wildlife); Hixon v. Pub. Serv. Comm'n, 146 N.W.2d 577, 582 (Wis. 1966) (referring to Wisconsin's public trust as encompassing sailing, swimming, hunting, and enjoyment of scenic beauty).

90. Hixon, 146 N.W.2d at 582.

91. Weden, 958 P.2d at 283-85.

92. Id.

93. See Borough of Neptune City v. Borough of Avon-By-The-Sea, 294 A.2d 47, 54-55 (N.J. 1972) (noting that "[t]he public trust doctrine, like all common law principles, should not be considered fixed or static, but should be molded and extended to meet changing conditions and needs of the public it was created to benefit").

94. Id. at 55 . 
Finally, Alaska has paid unusual attention to the access element of the public trust. ${ }^{95}$ The state has consistently protected an equal right of access to wildlife. ${ }^{96}$ This attention to access is probably a response to Alaska's population: an unusually large percentage of indigenous people whose livelihood is directly tied to the land. ${ }^{97}$ Despite a different motivation for access to public land than that enunciated in other states (i.e., livelihood rather than recreation), Alaska uses the same device, the public trust, to provide access. Thus, the hunting and fishing rights the Alaskan courts have derived from the trust are held by all residents of the state equally. This equal access stance may change if the wildlife populations suffer, but it remains an excellent, and perhaps the strongest, example of a state strongly protecting its citizens' right of access to the public trust.

\section{Application of Public Trust Doctrine to Land Trusts}

A land trust is no different than any other property owner when it comes to the public trust. To determine how the public trust would impact a land trust's holdings, the land trust must engage in a twostep analysis. First, it must determine which land that it owns, if any, is subject to the public trust. Second, it must discover what activities are protected by the public trust.

As discussed above, the geographic breadth of the public trust is determined by the state. ${ }^{98}$ At a minimum, if a land trust owns any navigable waterways, those would be subject to the public trust. ${ }^{99}$ In broader public trust states, much more land trust land could be subject to the public trust. When the land trust holds public trust land, it has the same responsibilities that any private owner of trust land would have. It must not take any action that would interfere with the public trust. Because the public trust has taken on a preservationist tone since the Sax article, ${ }^{100}$ and because land trusts are generally devoted to the preservation of land, that would not generally pose a problem: the goals of the public trust and the land trust are the same. The public trust bars significant alteration of the land, and the land

95. See Horner, supra note 51, at 66-68 (discussing the origins of the access element in Alaska's public trust).

96. Id. at $67-68$.

97. Id. at 66.

98. See supra note 68 and accompanying text.

99. See supra notes 57-59 and accompanying text.

100. See supra notes 65-67 and accompanying text. 
trust would have covenanted not to do so when it acquired the land. Thus far, there is no conflict between the land trust and the public trust.

In fact, their goals are so similar that land trusts may even be able to purchase state-owned public trust land-a privilege that a normal private citizen would not be able to enjoy. Although Illinois Central Railroad held that states may not sell public trust land, the decision did include an exception. When the sale is the interest of the public trust, the state may sell land that is held in the public trust. ${ }^{101} \mathrm{~A}$ state might want to make the sale because of limited financial resources. Land ownership is costly, and the state may want to minimize its costs by selling its public trust land to an organization dedicated to the preservation of land. Under most analyses, this kind of transaction would be unobjectionable, but it could pose a problem for the general public. If the land trust closes off the previously open public land, the sale has deprived the public of access to open space. This is precisely where the activities protected by the public trust become important.

As with geography, the state has the right to determine what activities are protected by the public trust. ${ }^{102}$ If the land trust is in a state with a broad, recreational public trust, the land trust would be required to allow access onto public trust lands for recreation. Then the sale would be truly unobjectionable: the land would be protected and the public enjoyment would be unimpaired. Moreover, because private property rights on public trust lands are subordinate to the public trust, the requirement that the organization make its public trust lands available for public trust activities cannot be considered a taking. ${ }^{103}$ If the public trust includes a recreational interest, it is an interest that the public possesses now, and can use now, without any further legal or legislative action. Therefore the scope of activities protected by each state's public trust is of critical importance. In a jurisdiction like Massachusetts, the public trust argument would have limited impact on land trusts because the trust only protects basic fishing and navigation rights. ${ }^{104}$ In a state like Washington, however,

101. Ill. Cent. R.R. Co. v. Illinois, 146 U.S. 387, 455-56 (1892).

102. See supra Part II.C.

103. See infra Part III.A.

104. See supra note 85 and accompanying text. 
the public trust would require land trusts to make their public trust land available for extensive recreational activities. ${ }^{105}$

\section{The Public TRUSt RESPONSE TO ACCESS-BARRING ARGUMENTS}

An access requirement to private land is controversial, and will almost certainly meet with some resistance. This Part will address two of the strongest arguments that opponents of public access are likely to offer in response to the argument made in this Note: takings and environmental necessity. Although both arguments are strong, neither should be seen as an absolute bar on public access to public trust land.

\section{A. Takings}

Any discussion of government-mandated public access to private land immediately invokes the specter of Nollan v. California Coastal Commission. ${ }^{106}$ The case that dramatically ushered in a new era of takings jurisprudence, ${ }^{107}$ Nollan stands for the proposition that uncompensated public access over private land is a per se taking. ${ }^{108}$ In the case, the Nollans owned a small beachfront house that they wanted to demolish and rebuild. ${ }^{109}$ The rebuilt house would have been larger and taller than the original. ${ }^{110}$ Because their house was in the Coastal Zone, they were subject to the authority of the California Coastal Commission, which approved the permit on the condition that the Nollans allow a beach access corridor across their land. ${ }^{111}$ Upon challenge, the Supreme Court held that there was not a sufficient nexus between the access requirement and the impact caused by the increased height to justify it as a proper exercise of the state's police power. ${ }^{12}$ Therefore, the access requirement was a per se taking. ${ }^{113}$

\footnotetext{
105. See supra note 89 and accompanying text.

106. 483 U.S. 825 (1987)

107. The revolution was not welcomed by all. Justice Brennan sharply dissented, claiming that the majority's nexus test "imposes a standard ... that has been discredited for the better part of [the] century." Id. at 842 (Brennan, J., dissenting).

108. Id. at 831-32.

109. Id. at 828 .

110. Id.

111. Id.

112. Id. at 837, 841-42.

113. Id.
} 
Although development exactions are not implicated by this Note (because the land trusts are not developing the land they hold), any sort of postpurchase access requirement that government could fashion would certainly be a per se taking. Just as in Nollan, the owners would be required to allow strangers to pass across their land at any time. This is the sort of easement that the Supreme Court in Nollan said the government "must pay for" ${ }^{\text {"114 }}$ if it determined that it was in the community's interest to have access to such lands. ${ }^{115}$

But Nollan does not absolutely bar public access to private land. The public trust doctrine requires at least limited public access to any land that is part of the public trust, whether it is held privately or publicly, and that access is not subject to a takings argument. When land is within the geographic scope of the public trust, private owners hold the land subject to the public trust; their rights are subordinate to those of the trust. ${ }^{116}$ Therefore, there is no taking because the private owner never actually owned the public trust stick of the bundle of ownership rights on the property. ${ }^{117}$ The owner cannot do anything that would interfere with the public trust. When the public trust includes the right to access and recreation, the owner may not do anything that will interfere with access and recreation. It is not a taking; it is a limitation the owner accepted when she purchased the land. Just as it is not a taking when the holder of an easement exercises her rights, it is not a taking when the beneficiary of the public trust, the public, exercises its rights with respect to public trust land.

The public trust argument is, of course, limited to public trust land. Land that is not part of the public trust will not be protected from a takings argument, but that does not mean that states are limited to protecting access only according to their public trust. State legislatures could protect access to future conservation land by mak-

\footnotetext{
114. Id. at 842 .

115. This, of course, assumes that the government is unwilling to acquire an access easement through its powers of eminent domain. If, on the other hand, the government were willing to exercise its power of eminent domain to secure the right of access for the public, the takings argument is moot.

116. See supra notes $60-61$ and accompanying text.

117. Lazarus, supra note 52, at 648 . This theory of takings could be interpreted to freeze the public trust at its current state in a particular jurisdiction because a judicial change might alter the property rights acquired by individual property owners. The Supreme Court, however, has repeatedly emphasized that judicial decisions of this kind do not constitute takings. Joseph L. Sax, The Limits of Private Rights in Public Waters, 19 ENVTL. L. 473, 477-78 n.11 (1989) (discussing the Supreme Court decisions holding that court decisions changing state property law cannot themselves be considered takings).
} 
ing a statutory change to their conservation easement statutes that would mandate public access to land held in a conservation easement. Because conservation easements are statutory creations, ${ }^{118}$ their properties can be changed. State legislatures can amend their conservation easement statutes to include a requirement that the holder of the easement make the land available for public use. In fact, some states already include this requirement. ${ }^{119}$ If a state legislature were persuaded to make this change, it would probably have to be prospective, to avoid a takings problem. But once the requirement was in place, any entity taking a conservation easement would be obliged to allow public access to the land covered by the easement.

\section{B. Environmental Protection}

The concept of "public access" is ill defined. One can easily understand the concern a land trust might feel about a stampede over its fragile ecosystem. Of course, this would not be the case. Sensible and reasonable environmental restrictions make sense to preserve the ultimate goal of conservation, and they are required by the balance between preservation of natural resources and preservation of access inherent in the public trust. ${ }^{120}$ But what if the land trust argued that the land must be completely protected from human contact to be properly conserved?

This could very well be true; some ecosystems could be so fragile that even having the occasional hiker pass through would be devastating. In these cases, however, other environmental laws would trump. Just as the public trust doctrine trumps the private property owner's rights, ${ }^{121}$ the Endangered Species Act would trump the public trust. ${ }^{122}$ For example, the public trust universally allows navigation and fishing. However, a public trust argument would not relieve one

\footnotetext{
118. See supra notes 21-29 and accompanying text.

119. See supra note 29 and accompanying text.

120. See, e.g., Weden v. San Juan County, 958 P.2d 273, 284 (Wash. 1998) (holding that the needs of resource protection prevented jet-skis from claiming public trust access protection). For a full discussion of the case, see supra note 91 and accompanying text.

121. See supra notes 60-61 and accompanying text.

122. The issue of conflict between protected public trust activities has never been litigated, but given the broad authority granted to the Environmental Protection Agency through the Endangered Species Act, this seems a very reasonable assumption. See Tulare Lake Basin Water Storage Dist. v. United States, 49 Fed. Cl. 313, 314-17, 324 (2001) (holding that, although the California State Water Resources Control Board had the right, pursuant to the Endangered Species Act, to deprive the plaintiff water permit holders of water in order to preserve two species of fish, the permit holders were entitled to compensation for their loss).
} 
of liability for "taking" an endangered fish while exercising the right to fish. Environmental reasons may preclude public access in some areas and limit it in many others, but the fundamental need for public access cannot be avoided based on environmental arguments. Just as the federal government varies access to some federal lands for environmental reasons, land trusts could be expected to make case-bycase stewardship decisions to maintain both public access and the environmental integrity of the land.

\section{CONCLUSION}

Land trusts provide a valuable social service by stepping in where the government does not to preserve land through private means. However, the value of that service is severely limited when the land trust then closes off its prize from the public. As a matter of public policy, the trusts should provide public access in return for the valuable tax breaks they enjoy. This could be enforced prospectively without creating a taking by amending the state's conservation easement statute to require the holder of a conservation easement to allow public access on the land. As a practical matter, the public trust doctrine currently mandates access to certain kinds of land, no matter whom the owner. It dictates that land subject to the public trust must be made available for all purposes the public trust encompasses. When the state has defined its public trust to include a recreational interest, the land trust would have little choice but to make its public trust land available.

Moreover, it is in the trust's interest to open its land. By providing public access and finding a third way between preservationists and recreationists, land trusts will bring a powerful ally to their side: the outdoor enthusiasts whose love of the land is built on years of long association with it. 